\title{
Influence of dexamethasone and weight loss on the regulation of serum leptin levels in obese individuals
}

D.D.G. Lerario,

S.R.G. Ferreira,

W.L. Miranda and A.R. Chacra

\author{
Disciplina de Endocrinologia, Departamento de Medicina, \\ Escola Paulista de Medicina, Universidade Federal de São Paulo, \\ São Paulo, SP, Brasil
}

\section{Correspondence \\ D.D.G. Lerario \\ Disciplina de Endocrinologia \\ EPM, UNIFESP \\ Rua Pedro de Toledo, 910 \\ 04039-000 São Paulo, SP \\ Brasil \\ Fax: + 55-11-5576-4474 \\ E-mail: dlerario@ osite.com.br \\ Research supported by FAPESP (No. 97/12771-7)}

Received December 7, 1999 Accepted January 30, 2001

\section{Abstract}

The adipocyte hormone leptin is thought to serve as a signal to the central nervous system reflecting the status of fat stores. Serum leptin levels and adipocyte leptin messenger RNA levels are clearly increased in obesity. Nevertheless, the factors regulating leptin production are not fully understood. The aim of this study was to determine the effects of in vivo administration of the synthetic glucocorticoid dexamethasone and weight loss on serum leptin levels in two independent protocols. Twenty-five obese subjects were studied (18 women and $7 \mathrm{men}$, mean age $26.6 \pm 6$ years, BMI $31.1 \pm 2.5 \mathrm{~kg} / \mathrm{m}^{2}, \%$ fat 40.3 \pm 8.3 ) and compared at baseline to 22 healthy individuals. Serum levels of leptin, insulin, proinsulin and glucose were assessed at baseline and after ingestion of dexamethasone, $4 \mathrm{mg}$ per day ( $2 \mathrm{mg}$, twice daily) for two consecutive days. To study the effects of weight loss on serum leptin, 17 of the obese subjects were submitted to a lowcalorie dietary intervention trial for 8 weeks and again blood samples were collected. Serum leptin levels were significantly higher in the obese group compared to the control group and a high positive correlation between leptinemia and the magnitude of fat mass was found $(\mathrm{r}=0.88, \mathrm{P}<0.0001)$. After dexamethasone, there was a significant increase in serum leptin levels $(22.9 \pm 12.3$ vs $51.4 \pm 23.3 \mathrm{ng} / \mathrm{ml}$, $\mathrm{P}<0.05)$. Weight loss $(86.1 \pm 15.1$ vs $80.6 \pm 14.2 \mathrm{~kg}, \mathrm{P}<0.05)$ led to a reduction in leptin levels $(25.13 \pm 12.8$ vs $15.9 \pm 9.1 \mathrm{ng} / \mathrm{ml}, \mathrm{P}<0.05)$. We conclude that serum leptin levels are primordially dependent on fat mass magnitude. Glucocorticoids at supraphysiologic levels are potent secretagogues of leptin in obese subjects and a mild fat mass reduction leads to a disproportionate decrease in serum leptin levels. This suggests that, in addition to the changes in fat mass, complex nutritional and hormonal interactions may also play an important role in the regulation of leptin levels.
Key words - O besity

- Leptin

- Weight reduction

- Dexamethasone 


\section{Introduction}

The notion that genetic abnormalities contribute to obesity has gained important support with the identification of the $o b$ gene and its protein product in 1994 (1). Leptin is a 167-amino acid peptide produced in adipose tissue in proportion to body fat and is thought to act as an afferent satiety signal in a feedback loop that putatively affects the appetite and satiety centers of the brain. The ultimate effect of this loop is to regulate body fat mass $(2,3)$.

In rodent models of obesity, leptin plays a key regulatory role in energy balance via the hypothalamus, with its action being mediated by specific leptin receptors $(4,5)$. In the arcuate nucleus, leptin interacts with neuropeptide Y (NPY), which is postulated to sense and respond to alterations in energy balance: a decrease in NPY may result in hypophagia and increased brown adipose tissue activity (6). Defective production of leptin in the ob/ob mouse produces a model of gross obesity, severe insulin resistance and infertility. When the mice receive leptin they stop eating and lose weight (7). Diabetes $(\mathrm{db})$, another well-characterized recessive obesity mutation, also results in profound and early onset obesity (8). Differently from ob/ob, db/db mice are not defective in their ability to produce leptin, but show resistance to its action (8).

Like $\mathrm{db} / \mathrm{db}$ mice, humans also seem to produce leptin normally. Some studies conducted on obese humans have shown a strong positive correlation between serum leptin concentrations and percentage of body fat, body mass index (BMI) and basal serum insulin concentrations $(9,10)$. These studies suggest that the human adipocytes produce leptin when the adipose mass increases and that there is resistance to the action of leptin, so that the increase in adipose tissue mass is maintained.

Under normal feeding conditions, leptin levels are strongly correlated with body fat mass and a reduction of adiposity leads to decreased leptinemia (10-12). Nevertheless, in some situations such as fasting and massive overfeeding, leptin levels are downregulated and up-regulated independently of changes in fat mass (13).

Furthermore, a number of hormones including insulin, catecholamines, sexual steroids and cortisol have been shown to modulate leptin synthesis in vitro and in vivo (1416). Cortisol and insulin have long been implicated in energy balance and their interaction with leptin is believed to constitute a feedback loop for the maintenance of body weight (17). Considering the anti-obesity action of leptin, it seems reasonable that the hypercortisolism which classically induces hyperphagia and obesity could be counterregulated by an activation of the $o b$ gene leading to hyperleptinemia.

The real physiological role of leptin in humans as well as the mechanisms that regulate its secretion are still a matter of discussion. Leptin levels are directly related to fat mass, but other mechanisms independent of adiposity also have a strong influence on the serum levels of the $o b$ gene product. The effects of glucocorticoids on leptinemia in humans have not been totally clarified. In some studies, acute administration of glucocorticoids has raised leptinemia $(16,18-21)$, while in other reports such results were not observed (14,22). In addition, only a few studies have been performed on humans with obesity $(18,19)$.

In the present study we investigated the behavior of serum leptin levels in two different protocols: after short-term dexamethasone administration and after a weight reduction program in obese individuals. The objective was to evaluate the influence of each of these two factors on leptin secretion.

\section{Patients and Methods}

Twenty-five obese subjects (18 women and 7 men, mean age $26.6 \pm 6$ years, BMI 31.1 
$\pm 2.5 \mathrm{~kg} / \mathrm{m}^{2}, \%$ fat $40.3 \pm 8.3$ ) were studied at baseline (Table 1), after dexamethasone treatment and after a weight loss program. Obesity was defined according to the National Institutes of Health Technology Assessment Conference Panel criteria (23) as BMI greater than 27.3 for women and greater than 27.8 for men, which is approximately $120 \%$ of ideal body weight. Blood pressure was measured in the supine position and hypertension was considered to be present at systolic blood pressure $>140 \mathrm{mmHg}$ and diastolic blood pressure $>90$ $\mathrm{mmHg}(24)$.

Twenty-two healthy individuals (15 women and 7 men, mean age $23.4 \pm 3.8$ years, BMI $20.0 \pm 2.5 \mathrm{~kg} / \mathrm{m}^{2}$, \%fat $24.0 \pm$ 5.8) served as a control group for baseline hormone comparison (Table 1). None of the 47 individuals admitted to the study were taking any drugs or had any evidence of metabolic disease other than obesity. Their weight was stable for at least 3 months before the study. Anthropometric measurements were performed on each participant, all of them barefoot and casually dressed. Height (m) and weight $(\mathrm{kg})$ were determined to calculate BMI as weight/height ${ }^{2}$. Waist circumference was only measured in the obese individuals, at the narrowest point above to the hip, and was divided by the circumference of the hip, measured at its greatest gluteal protuberance, to obtain the waist-tohip ratio. Body composition was measured by dual energy X-ray absorptiometry (DEXA; Hologic, Bedford, MA, USA). The study was approved by the Ethics Committee of Escola Paulista de Medicina, UNIFESP. Written informed consent was obtained from all subjects before their participation in the study.

\section{Baseline evaluation}

Obese group. After a 12-h overnight fast, blood was drawn for the determination of serum leptin, glucose, insulin, proinsulin and cortisol. Renal, hepatic and thyroid func- tions were also assessed. The oral glucose tolerance test was performed to ascertain that the obese subjects were nondiabetic. Normal glucose tolerance was defined according to the new World Health Organization criteria and ADA Committee Report $(25,26)$. Anthropometric measurements were made and body composition was assessed by DEXA.

Control group. After a 12-h overnight fast, blood was drawn for leptin, insulin and proinsulin analysis. Anthropometric measurements were made and body composition was assessed by DEXA.

Dexamethasone protocol. Dexamethasone was administered twice daily at the dose of $2 \mathrm{mg}$ for two days (total dose, $8 \mathrm{mg}$ ). On the following morning, after a 12-h fast, blood samples were drawn for leptin, insulin, proinsulin, cortisol and glucose analysis.

Weight reduction protocol. Seventeen of the 25 obese individuals were submitted to a weight reduction program. They were instructed to follow a diet containing 1000 kcal less than the calculated daily energy requirements for each individual $(55 \%$ carbohydrates, $15 \%$ protein, $30 \%$ fat) for 8 weeks. After this period, samples were drawn for leptin, insulin and proinsulin analysis. Anthropometric measurements were made and body composition was assessed again.

Table 1 - Clinical and anthropometric parameters of the obese and control groups.

Data are reported as means \pm SD. $* \mathrm{P}<0.03$ for age, BMI, fat mass and \%fat (independent samples t-test).

\begin{tabular}{lcc}
\hline & Obese & Control \\
\hline $\mathrm{N}$ & 25 & 22 \\
Sex (female/male) & $18 / 7$ & $15 / 7$ \\
Age (years) & $26.6 \pm 6.0^{*}$ & $23.4 \pm 3.8$ \\
BMI (kg/m²) & $31.1 \pm 2.5^{*}$ & $20.0 \pm 2.5$ \\
Fat mass $(\mathrm{kg})$ & $31.8 \pm 5.8^{*}$ & $12.9 \pm 3.5$ \\
$\%$ Fat & $40.3 \pm 8.3^{*}$ & $24.0 \pm 5.8$
\end{tabular}


Assays

Leptin, specific insulin and proinsulin were measured in duplicate using commercial radioimmunoassay kits (Linco Research Inc., St. Charles, MO, USA). For insulin the limit of sensitivity was $2 \mu \mathrm{IU} / \mathrm{ml}$ and the intra- and interassay coefficients of variation were $<10 \%$. Cross-reactivity was $<0.2 \%$ with human proinsulin and $100 \%$ with human insulin. Normal fasting range: $5-15 \mu \mathrm{IU} / \mathrm{ml}$. For the proinsulin assay the limit of sensitivity was $2 \mathrm{pM} / \mathrm{ml}$ and intra- and interassay coefficients of variation were $<10 \%$. Crossreactivity with human insulin and human $\mathrm{C}$ peptide was $<0.1 \%$. Leptin radioimmunoassay using a polyclonal antibody raised in rabbits against highly purified recombinant human leptin (27) presented coefficients of variation for within and between analyses ranging from 3.6 to $8.2 \%$ and from 3.5 to $6.1 \%$, respectively. Serum glucose was determined by an enzymatic method, using a Selectra 2 glucose analyzer (Merck S.A., Rio de Janeiro, RJ, Brazil). Cortisol was also measured in duplicate using a specific radioimmunoassay.

\section{Statistical analysis}

Statistical analysis was performed using the SPSS program, version 7.0 for Windows 95 (SPSS Inc., Chicago, IL, USA). The obese

Table 2 - Serum glucose, leptin, insulin, proinsulin and cortisol levels before and after dexamethasone administration to obese individuals.

Data are reported as means $\pm \mathrm{SD}$. $* \mathrm{P}<0.003 \mathrm{com}$ pared to baseline (Student t-test).

Baseline

After dexamethasone

Glucose $(\mathrm{mg} / \mathrm{dl}) \quad 89.8 \pm 5.7104 .6 \pm 16.6^{*}$ Leptin $(\mathrm{ng} / \mathrm{ml}) \quad 22.9 \pm 12.3 \quad 51.4 \pm 23.3^{*}$ Insulin $(\mu \mathrm{IU} / \mathrm{ml}) \quad 25.8 \pm 16.1 \quad 57.8 \pm 32.6^{*}$ Proinsulin $(\mathrm{pM} / \mathrm{ml}) \quad 15.9 \pm 11.4 \quad 32.5 \pm 28.0^{*}$ Cortisol $(\mu \mathrm{g} / \mathrm{dl}) \quad 15.8 \pm 9.2 \quad 0.8 \pm 0.5^{*}$ and control group variables were compared by the $t$-test for independent samples. The correlation between leptin and other variables was established using the Pearson correlation test. Data obtained at baseline, after dexamethasone and after weight loss were compared by the Student $t$-test. Results are reported as means $\pm \mathrm{SD}$. Differences were accepted as significant at $\mathrm{P}<0.05$.

\section{Results}

\section{Baseline evaluations}

The levels of leptin $(22.9 \pm 12.3$ vs $5.7 \pm$ $3.2 \mathrm{ng} / \mathrm{ml}), \mathrm{P}<0.0001)$, insulin $(25.8 \pm 16.1$ vs $16.3 \pm 8.4 \mu \mathrm{IU} / \mathrm{ml}, \mathrm{P}=0.01)$ and proinsulin $(15.9 \pm 11.4$ vs $9.0 \pm 2.8 \mathrm{pM} / \mathrm{ml}), \mathrm{P}=$ $0.006)$ were significantly higher in the obese group compared to the control group. Baseline plasma leptin levels correlated highly with the percentage of fat $(r=0.88$, $\mathrm{P}<0.0001)$. Fasting and after load glucose levels were $89.8 \pm 5.7$ and $99.2 \pm 26.1 \mathrm{mg} / \mathrm{dl}$, respectively, in obese individuals. A significant correlation was also observed with $\mathrm{BMI}$ $(\mathrm{r}=0.68, \mathrm{P}<0.0001)$, insulin $(\mathrm{r}=0.29, \mathrm{P}=$ $0.048)$ and proinsulin $(\mathrm{r}=0.4, \mathrm{P}=0.005)$. Baseline leptin levels were three-fold higher in women than in men $(\mathrm{P}<0.0001)$. Nevertheless, when the data were adjusted for fat percentage the difference was no longer significant.

\section{Dexamethasone protocol}

Dexamethasone administration suppressed endogenous cortisol in all subjects, indicating good compliance with the protocol (Table 2). No adverse effects or weight change $(85.1 \pm 15.2$ vs $85.4 \pm 15.1 \mathrm{~kg}, \mathrm{P}=$ 0.96 , before and after dexamethasone, respectively) were observed. Leptin levels increased significantly (Table 2 ) and the magnitude of serum leptin elevation (absolute variation in leptin levels) was dependent on increasing body fat mass values $(\mathrm{r}=0.68$, 
$\mathrm{P}<0.0001$ ) (Figure 1). Serum levels of insulin, proinsulin and glucose were also significantly increased (Table 2). One male subject presented fasting glucose at diabetic levels $(177 \mathrm{mg} / \mathrm{dl})$ after the use of dexamethasone, which normalized within a short term.

No correlation was established between the change in insulin, proinsulin and glucose levels after dexamethasone and leptin variation $(\mathrm{r}=0.21, \mathrm{P}=0.3 ; \mathrm{r}=0.07, \mathrm{P}=0.75 ; \mathrm{r}=$ $0.17, \mathrm{P}=0.43$, respectively). Plasma insulin variation after dexamethasone was correlated with waist circumference and waist-tohip ratio; however, such correlation was only significant in relation to waist circumference $(\mathrm{r}=0.4, \mathrm{P}=0.047 ; \mathrm{r}=0.35, \mathrm{P}=0.09$, respectively). Leptin variation after dexamethasone tended to be greater in women $(31.5 \pm 12.5 \mathrm{ng} / \mathrm{ml})$ than in men $(20.5 \pm 14.8$ $\mathrm{ng} / \mathrm{ml}$ ), but the difference was not statistically significant $(\mathrm{P}=0.07)$.

\section{Weight reduction protocol}

There was a significant weight and body fat mass reduction (Table 3). Weight loss was mostly explained by fat mass reduction. However, a significant decrease in lean body mass was also observed (Table 3). BMI, waist circumference and diastolic blood pressure also decreased significantly (Table 3 ). Serum leptin showed a significant $36.6 \%$ decrease from baseline values (Table 3 ). Serum insulin and proinsulin levels also decreased after weight loss, but the difference was not statistically significant (Table 3 ). The BMI and fat mass variations were significantly correlated with leptin change after weight loss $(\mathrm{r}=0.55, \mathrm{P}=0.02 ; \mathrm{r}=0.63, \mathrm{P}=$ 0.006 , respectively).

\section{Discussion}

Our data clearly show that obese individuals have increased serum leptin, insulin and proinsulin levels when compared to a non-obese group.

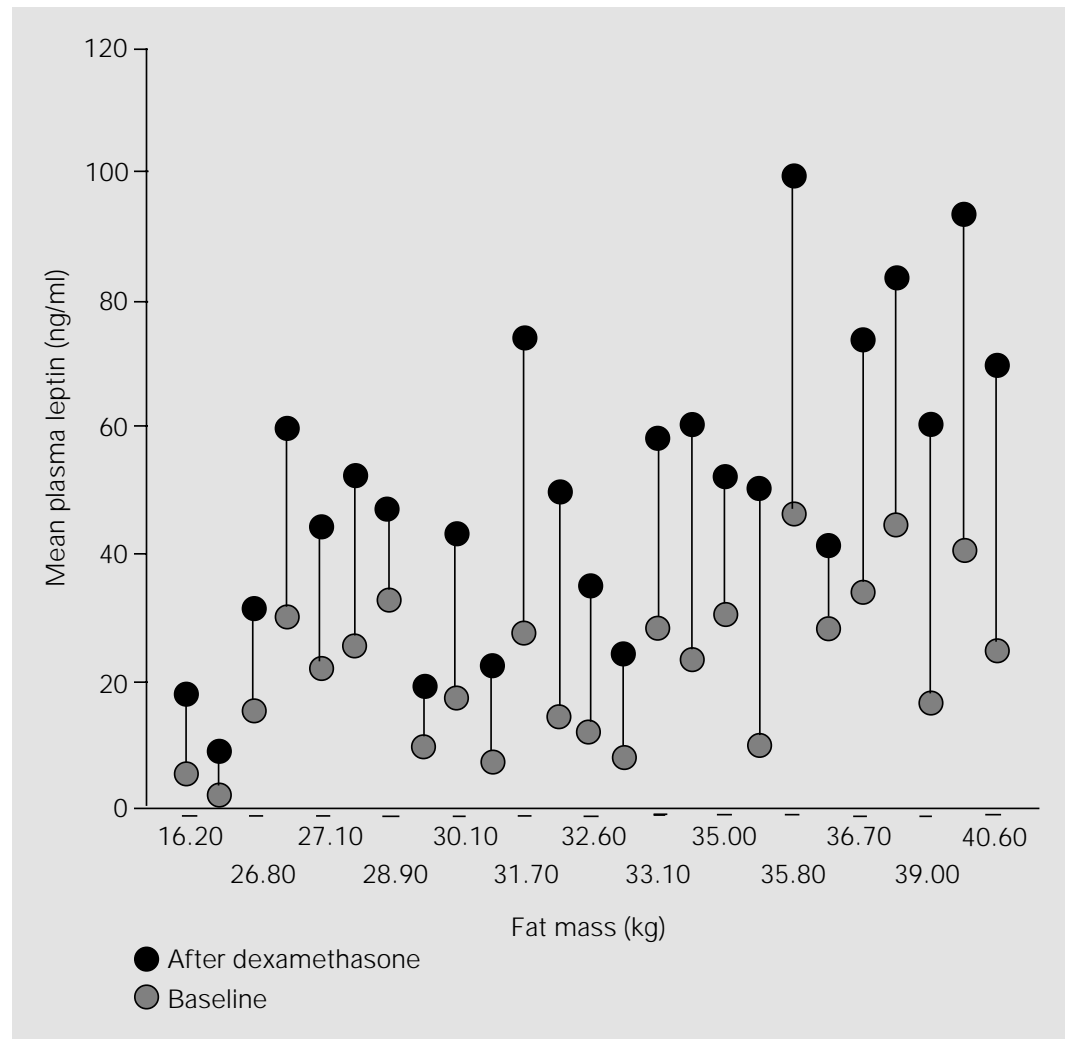

Figure 1 - Increase in serum leptin after dexamethasone treatment. Leptin variation was plotted against basal fat mass for 25 obese subjects.

Table 3 - Clinical, anthropometric and hormonal parameters of obese subjects submitted to a weight loss program, at baseline and after weight loss.

Data are reported as means \pm SD. BMI, Body mass index; WHR, waist-to-hip ratio; SBP, systolic blood pressure; DBP, diastolic blood pressure; NS, not significant.

\begin{tabular}{lccc}
\hline & Baseline & After weight loss & P value \\
\hline Weight $(\mathrm{kg})$ & $86.1 \pm 15.1$ & $80.6 \pm 14.2$ & $<0.05$ \\
BMI $\left(\mathrm{kg} / \mathrm{m}^{2}\right)$ & $31.6 \pm 2.7$ & $29.6 \pm 2.7$ & $<0.05$ \\
Waist $(\mathrm{cm})$ & $94.8 \pm 9$ & $89.5 \pm 9.4$ & $<0.05$ \\
WHR & $0.87 \pm 0.04$ & $0.86 \pm 0.03$ & NS \\
SBP $(\mathrm{mmHg})$ & $133.2 \pm 16.6$ & $126.7 \pm 13.6$ & $\mathrm{NS}$ \\
DBP $(\mathrm{mmHg})$ & $88.2 \pm 11.6$ & $80.8 \pm 8.1$ & $<0.05$ \\
\%Fat & $40.7 \pm 8.1$ & $39.6 \pm 8.1$ & $<0.05$ \\
Fat mass $(\mathrm{kg})$ & $32.6 \pm 6.1$ & $29.3 \pm 5.3$ & $<0.0001$ \\
Lean body mass $(\mathrm{kg})$ & $48.7 \pm 12.9$ & $47.6 \pm 12.2$ & $<0.05$ \\
Insulin $(\mu \mathrm{IU} / \mathrm{ml})$ & $27.2 \pm 17.6$ & $20.2 \pm 6.4$ & $\mathrm{NS}$ \\
Leptin $(\mathrm{ng} / \mathrm{ml})$ & $25.1 \pm 12.8$ & $15.9 \pm 9.1$ & $<0.05$ \\
Proinsulin $(\mathrm{pM} / \mathrm{ml})$ & $14.1 \pm 9.9$ & $11.1 \pm 3.8$ & $\mathrm{NS}$
\end{tabular}


Leptin levels were significantly correlated with fat mass magnitude, plasma insulin and proinsulin. This is in accordance with other studies $(28,29)$, including a Brazilian one by Pardini et al. (30). However, in a South Asian population leptin levels were not correlated with insulin and proinsulin, showing an ethnic variation in this association due to unknown reasons (31). The association between hyperleptinemia and hyperinsulinemia is a characteristic of obesity and both conditions reflect a state of hormone resistance. Recent studies on adipocyte cell lines and on animal models of obesity have shown that insulin stimulates leptin gene expression $(32,33)$. In contrast, in humans the effect of insulin on plasma leptin is more controversial. Short-term insulinemia, such as after food intake, has not been demonstrated to affect leptin levels, unless the acute hyperinsulinemia is extended beyond $48 \mathrm{~h}$ (5).

Concerning the glucocorticoid protocol, our data have shown that after a two-day administration of supraphysiological doses of dexamethasone there was over a two-fold increase (124\%) in leptin without any change in body weight. Most studies carried out to determine the effects of dexamethasone on leptinemia were performed in non-obese individuals and in general led to increases in leptinemia $(16,20,21,34,35)$. Two studies involved obese populations $(18,19)$. Kiess et al. (18) administered $1.5 \mathrm{mg} / \mathrm{m}^{2}$ of dexamethasone to obese children and obtained a $26.3 \%$ increase in leptinemia. Dagogo-Jack et al. (19) observed a 75\% elevation in leptinemia in an older population (mean age $41.9 \pm 4.0$ years) after $10 \mathrm{mg}$ of dexamethasone with similar responses in both sexes. Our results showed a greater leptinemia response, with women tending to show higher variation. We suggest that this difference in serum leptin change after dexamethasone between sexes might be due to the predominance of subcutaneous fat mass in women which was shown to produce more leptin than the visceral adipose tissue (36).

In other studies, however, dexamethasone was shown to decrease leptin gene expression in mouse adipocytes (37), and methylprednisolone reportedly had no effect on leptin secretion (22). A very important result of the present study is that leptinemia was substantially increased after dexamethasone administration, independent of any variation in body weight. Our study has definitely shown that dexamethasone administered for two days at supraphysiologic doses to obese individuals can increase leptin secretion. In spite of the high basal leptinemia that usually accompanies the high percentage of fat in obese individuals, this significant rise in leptin levels after dexamethasone demonstrates that the adipocytes were not at their maximum capacity to secrete leptin. However, the mechanism by which dexamethasone stimulates leptin release, whether by a direct action on the $o b$ gene or via induced hyperinsulinemia, still remains controversial.

We did not find any significant correlation between leptin and insulin variation after dexamethasone, a fact that might suggest that leptin levels were increased by a direct action of glucocorticoids on the $o b$ gene rather than induced by hyperinsulinemia. Nevertheless, it is possible that the doubling of fasting insulin levels induced by dexamethasone contributed to the increase in leptinemia observed. As shown by various studies, the parallel rise in leptin mRNA levels and serum leptin levels after dexamethasone administration in vivo and in vitro strongly suggests that the effect is mediated at the mRNA level $(15,16,18,21)$.

Kolaczynski et al. (16), however, unexpectedly observed unchanged $o b$ gene expression after ingestion of $10 \mathrm{mg}$ dexamethasone despite a doubling of serum leptin levels. In their study, short-term clamped hyperinsulinemia had no additional effect on the elevation of leptin. The study by Larsson and Ahrén (20) showed a rise in 
leptin levels after $15 \mathrm{mg}$ of dexamethasone independent of the degree of change in insulin sensitivity, suggesting that the effect of dexamethasone could be a direct result of the steroid on $o b$ gene expression in adipose tissue. Another interesting study by Berneis et al. (35) found an increase in leptin levels after treatment with growth hormone and glucocorticoids, despite a decrease in body fat. This suggested that serum leptin is regulated by glucocorticoids, possibly through changes in insulin secretion, independent of variations in body fat mass.

As discussed by Papaspyrou-Rao et al. (21), additional studies of the time course of the effects of glucocorticoid and insulin during clamped conditions are needed to determine whether dexamethasone stimulates leptin without concomitant hyperinsulinemia, how rapidly this effect occurs, and if there are gender- or obesity-related differences in responsiveness to these hormones. It is of great importance to better understand the interaction among glucocorticoids, insulin and leptin since glucocorticoids and insulin are major antagonistic long-term regulators of energy balance (17) and leptin is a sensing parameter for the adipose tissue that putatively acts as a satiety factor. The observation that dexamethasone, even at physiological doses, potently induced $o b$ gene expression suggests that glucocorticoids are involved physiologically in the regulation of leptin secretion in vivo (34). A loop system might be envisioned in which food intake could trigger insulin and glucocorticoid output, thereby favoring fat accumulation and the secretion of leptin, subsequently causing satiation (2).

Our data also showed an out-of-proportion fall in leptin levels (36.6\%) in relation to a mild weight loss (6.4\%). Considine et al. (10) found a reduction in serum leptin concentration of about $53 \%$ in seven individuals after a $10 \%$ body weight loss. Other authors obtained similar results regarding a dramatic decrease in leptin concentration, without a comparable alteration in BMI or fat mass $(11,12)$. This suggests that a relative deficiency in leptin may cause an increase in appetite and a decrease in energy expenditure, in accordance with the effects of leptin deficiency observed in animals. This hypothesis could explain, at least in part, the high rate of relapse after weight reduction and the increased hunger and decreased energy expenditure in this situation (38). To date, there is no definitive answer about the factor responsible for the out-of-proportion decrease in serum leptin. It seems that, besides the variation in fat mass, the plasma leptin concentration after weight loss is also controlled by nutritional and hormonal factors. According to Geldszus et al. (12), a lowcalorie diet itself seems unlikely to explain the out-of-proportion fall in leptin levels. In the cited study, an unrestricted diet following a weight reduction program did not explain the difference in serum leptin compared to the control subjects who never lost weight. However, another study demonstrated that the fall in serum leptin during fasting can be prevented by infusion of small amounts of glucose, suggesting that leptin release might have been influenced by serum insulin (13). In our patients, we observed a reduction in insulin levels after weight loss, which, however, was not statistically significant. Nor did we find any correlation between leptin and insulin reduction after weight loss.

An evolutionary theory proposed by Flier (39) hypothesizes that a potent anti-obesity adipostatic system would be selected under conditions of food scarcity. Thus, according to this theory, the dominant role of leptin would be triggering neuroendocrine responses when its plasma levels are decreased. The out-of-proportion fall in leptin levels during a low-calorie diet would be a signal to the brain of energy insufficiency and of the need to activate compensatory responses. The anti-obesity action of leptin in humans, however, has already been described in two 
children with a homozygous mutation in the leptin gene and severe obesity (40). This indicates that leptin is also important as a factor to avoid hyperphagia and weight gain. We hope that further studies will expand our understanding concerning the kinetics of leptin secretion that appears to be extremely susceptible to up- and down-regulation by fat mass-dependent and fat mass-independent factors.
We conclude that plasma leptin levels are primordially dependent on fat mass magnitude. Glucocorticoids are potent secretagogues of leptin in obese individuals. A mild fat mass reduction leads to an out-of-proportion decrease in serum leptin levels. This suggests that, in addition to the changes in fat mass, complex nutritional and hormonal interactions may also play an important role in the regulation of leptin levels.

\section{References}

1. Zhang Y, Proenca R, Maffei M, Barone M, Leopold L \& Friedman J M (1994). Positional cloning of the mouse obese gene and its human homologue. Nature, 372: 425-431.

2. Caro J F, Sinha MK, Kolaczynski J W, Zhang PL \& Considine RV (1996). Leptin: the tale of an obesity gene. Diabetes, 45: 14551462.

3. Collins S, Kuhn CM, Petro AE, Swick AG, Chrunyk BA \& Surwit RS (1996). Role of leptin in fat regulation. Nature, 380: 677.

4. Matson CA, Wiater MF \& Weigle DS (1996). Leptin and the regulation of body adiposity. Diabetes Reviews: 4: 488-508.

5. Qureshi A \& Kopelman PG (1997). Leptin fat messenger or fat controller? Clinical Endocrinology, 47: 169-171.

6. Stephens TW, Basinski M, Bristow PK, Bue-Valleskey J M, Burgett SG, Craft L, Hale J, Hoffmann J, Hsiung HM, Kriauciunas A, McKellar J r W, Rostech PR, Schoner B, Smith D, Tasley FC, Zhang XY $\&$ Heiman M (1995). The role of neuropeptide $Y$ in the antiobesity action of the obese gene product. Nature, 377: 530532.

7. Pelleymounter MA, Cullen MJ , Baker MB, Hecht R, Winters D, Boone T \& Collins F (1995). Effects of the obese gene product on body weight regulation in ob/ob mice. Science, 269: 540-543.

8. Coleman DL (1973). Effects of parabiosis of obese with diabetes and normal mice. Diabetologia, 9: 294-298.

9. Sinha MK, Ohannesian JP, Heiman ML, Kriauciunas A, Stephens TW, Magosin S, Marco C \& Caro J F (1996). Nocturnal rise of leptin in lean, obese, and non-insulindependent diabetes mellitus subjects. J ournal of Clinical Investigation, 97: 13441347.

10. Considine RV, Sinha MK, Heiman ML,
Kriauciunas A, Stephens TW, Nyce MR, Ohannesian J P, Marco CC, McKee LJ, Bauer TL \& Caro J F (1996). Serum immunoreactive-leptin concentrations in normal-weight and obese humans. New England J ournal of Medicine, 334: 292-295.

11. Scholz GH, Englaro P, Thiele I, Scholz M, Klusmann T, Rascher $W \&$ Blum WF (1996). Dissociation of serum leptin concentration and body fat content during long term dietary intervention in obese individuals. Hormone and Metabolic Research, 28: 718-723.

12. Geldszus R, Mayr B, Horn R, Geinsthövel F, Mühlen AVZ \& Brabant G (1996). Serum leptin and weight reduction in female obesity. European J ournal of Endocrinology, 135: 659-662.

13. Boden $\mathrm{G}$, Chen $\mathrm{X}$, Mozzoli $\mathrm{M} \&$ \& Ryan I (1996). Effect of fasting on serum leptin in normal human subjects. J ournal of Clinical Endocrinology and Metabolism, 81: 3419-3423.

14. Casabiell $X$, Piñeiro $V$, Peino $R$, Lage $M$, Camiña J , Gallego R, Vallejo LG, Dieguez $C \&$ Casanueva FF (1998). Gender differences in both spontaneous and stimulated leptin secretion by human omental adipose tissue in vitro: dexamethasone and estradiol stimulate leptin release in women, but not in men. J ournal of Clinical Endocrinology and Metabolism, 83: 2149-2155.

15. De Vos P, Saladin R, Auwerx J \& Staels B (1995). Induction of ob gene expression by corticosteroids is accompanied by body weight loss and reduced food intake. J ournal of Biological Chemistry, 270: 1595815961.

16. Kolaczynski J W, Goldstein BJ \& Considine RV (1997). Dexamethasone, ob gene, and leptin in humans; effect of exogenous hyperinsulinemia. J ournal of Clinical Endo- crinology and Metabolism, 82: 3895-3897.

17. Strack AM, Sebastian RJ, Schwartz MW \& Dallman MF (1995). Glucocorticoids and insulin: reciprocal signals for energy balance. American J ournal of Physiology, 268: R142-R149.

18. Kiess W, Englaro $P$, Hanitsch $S$, Rascher W, Attanasio A \& Blum WF (1996). High leptin concentrations in serum of very obese children are further stimulated by dexamethasone. Hormone and Metabolic Research, 28: 708-710.

19. Dagogo-J ack S, Selke G, Melson AK \& Newcomer J W (1997). Robust leptin secretory responses to dexamethasone in obese subjects. J ournal of Clinical Endocrinology and Metabolism, 82: 3230-3233.

20. Larsson H \& Ahrén B (1996). Short-term dexamethasone treatment increases plasma leptin independently of changes in insulin sensitivity in healthy women. J ournal of Clinical Endocrinology and Metabolism, 81: 4428-4432.

21. Papaspyrou-Rao S, Schneider SH, Petersen RN \& Fried SK (1997). Dexamethasone increases leptin expression in humans in vivo. J ournal of Clinical Endocrinology and Metabolism, 82: 1635-1637.

22. Tataranni PA, Pratley R, Maffei N \& Ravussin E (1997). Acute and prolonged administration of glucocorticoid (methylprednisolone) does not affect plasma leptin concentration in humans. International J ournal of Obesity, 21: 327-330.

23. NIH Technology Assessment Conference Panel (1992). Methods for voluntary weight loss and control. Annals of Internal Medicine, 116: 942-949.

24. The Sixth Report of the J oint National Committee on Prevention, Detection, Evaluation and Treatment of High Blood Pressure (1997). Archives of Internal Medicine, 157: 2413-2446. 
25. WHO Expert Committee on Diabetes Mellitus (1985). Second report. Technical Report Series, 727. World Health Organization, Geneva.

26. The Expert Committee on the Diagnosis and Classification of Diabetes Mellitus (1997). Report of the Expert Committee on the Diagnosis and Classification of Diabetes Mellitus. Diabetes Care, 20: 11831197.

27. Ma Z, Gingerich RL, Santiago J V, Klein S, Smith CH \& Landt M (1996). Radioimmunoassay of leptin in human plasma. Clinical Chemistry, 42: 942-946.

28. Damani S, Gabriel M, Khan A, Boyadjian R, Kandar V \& Saad M (1996). Adiposity and insulinemia determine plasma leptin concentration. Diabetes, 45 (Suppl 1): 41A (Abstract).

29. Segal KR, Landt M \& Klein S (1996). Relationship between insulin sensitivity and plasma leptin concentration in lean and obese men. Diabetes, 45: 988-991.

30. Victória MNI, Pieroni FB, Milagres G, Purisch S, Pardini H \& Pardini VC (1997). Estudo da leptina, insulina e pró-insulina numa população de obesos brasileiros. Arquivos Brasileiros de Endocrinologia e Metabolismo, 41: 121-124.
31. Snehalatha $C$, Ramachandran A, Satyavani K, Vijay V \& Haffner SM (1998). Plasma leptin is not associated with insulin resistance and proinsulin in non-diabetic South Asian indians. Diabetic Medicine: 15: 480484.

32. Leroy $\mathrm{P}$, Dessolin $\mathrm{S}$, Villageois $\mathrm{P}$, Moon BC, Friedman J M, Aihaud G \& Dani C (1996). Expression of ob gene in adipose cells: regulation by insulin. J ournal of Biological Chemistry, 271: 2365-2368.

33. Wabitsch M, J ensen PB, Bum WF, Christoffersen $C T$, Englaro $P$, Heinze $E$, Rascher W, Teller W, Tornqvist $\mathrm{H}$ \& Hauner H (1996). Insulin and cortisol promote leptin production in cultured human fat cells. Diabetes, 45: 1435-1438.

34. Masuzaki $H$, Ogawa $H$, Hosoda $K$, Miywaki T, Hanaoka I, Hiraoka J, Yasuno A, Nishimura H, Yoshimasa Y, Nishi S \& Nakao K (1997). Glucocorticoid regulation of leptin synthesis and secretion in humans: elevated plasma leptin levels in Cushing's syndrome. J ournal of Clinical Endocrinology and Metabolism, 82: 25422547.

35. Berneis K, Vosmeer S \& Keller U (1996). Effects of glucocorticoids and growth hormone on serum leptin concentrations in man. European J ournal of Endocrinology, 135: 663-665.

36. Harmelen $W$, Reynisdottir $S$, Eriksson $P$, Thörne A, Hoffstedt J, Lönnqvist $F$ \& Arner P (1998). Leptin secretion from subcutaneous and visceral adipose tissue in women. Diabetes, 47: 913-917.

37. Rentsch J \& Chiesi M (1996). Regulation of ob gene mRNA levels in cultured adipocytes. FEBS Letters, 379: 55-59.

38. Leibel RL, Rosenbaum $M \&$ Hirsch J (1995). Changes in energy expenditure resulting from altered body weight. New England J ournal of Medicine, 332: 621628.

39. Flier JS (1998). What's in a name? In search of leptin's physiologic role. J ournal of Clinical Endocrinology and M etabolism, 83: 1407-1413.

40. Montague CT, Farooqi IS, Whitehead J $P$, Soos MA, Rau H, Wareham NJ, Sewter CP, Digby J E, Mohammed SN, Hurst J Á Cheetham $\mathrm{CH}$, Earley $\mathrm{AR}$, Barnett $\mathrm{AH}$, Prins J B \& O'Rahilly S (1997). Congenital leptin deficiency is associated with severe early-onset obesity in humans. Nature, 387: 903-908. 